MIDPI

\title{
sciforum
}

\section{The biodeterioration and blackening of vinyl glues: A new microbial cause and triaryl butene derivatives as new biocide}

Karim Jalleli ${ }^{1}$, Fatma Abdmouleh ${ }^{1}$, Mousser Hedrich ${ }^{2}$, Fatma Trigui ${ }^{1}$, Manel Ben Ali $^{1}$, Pascal Pigeon ${ }^{3}$, Siden Top ${ }^{3}$, Mamdouh Ben $\mathrm{Ali}^{1}$, Maher Bougacha ${ }^{4}$, Gérard Jaouen ${ }^{3}$ and Mehdi EL ARBI ${ }^{5, *}$

${ }^{1}$ Centre de Biotechnologie de Sfax (CBS), University of Sfax, Tunisia; jellali.karim@hotmail.com (Karim Jalleli); abdmouleh.fatma91@gmail.com (Fatma Abdmouleh); yangui.trigui.fatma@gmail.com (Fatma Trigui); zhmh80@yahoo.fr (Manel Ben Ali); mamdouh.benali@ cbs.rnrt.tn (Mamdouh Ben Ali)

${ }^{2}$ Institut Supérieure des Etudes Technologiques de Sfax, Tunisia; mousserhedrich@yahoo.fr (Mousser Hedrich)

${ }^{3}$ Institut Parisien de Chimie Moléculaire (IPCM), Université Pierre et Marie Curie-Paris, France; pascal.pigeon@chimieparistech.fr (Pascal Pigeon); siden.top@chimie-paristech.fr (Siden Top); gerard.jaouen@chimie-paristech.fr (Gérard Jaouen)

${ }^{4}$ Société Industrielle pour la Fabrication de la Colle et ses Dérivés «SIFCOL », Tunisia; maher611@hotmail.fr (Maher Bougacha)

${ }^{5}$ Institut Supérieur de Biotechnologie de Sfax (ISBS), University of, Tunisia; mehdi.elarbi@isbs.usf.tn (Mehdi EL ARBI)

* Author to whom correspondence should be addressed; E-Mail: mehdi.elarbi@isbs.usf.tn

\section{Graphical Abstract}

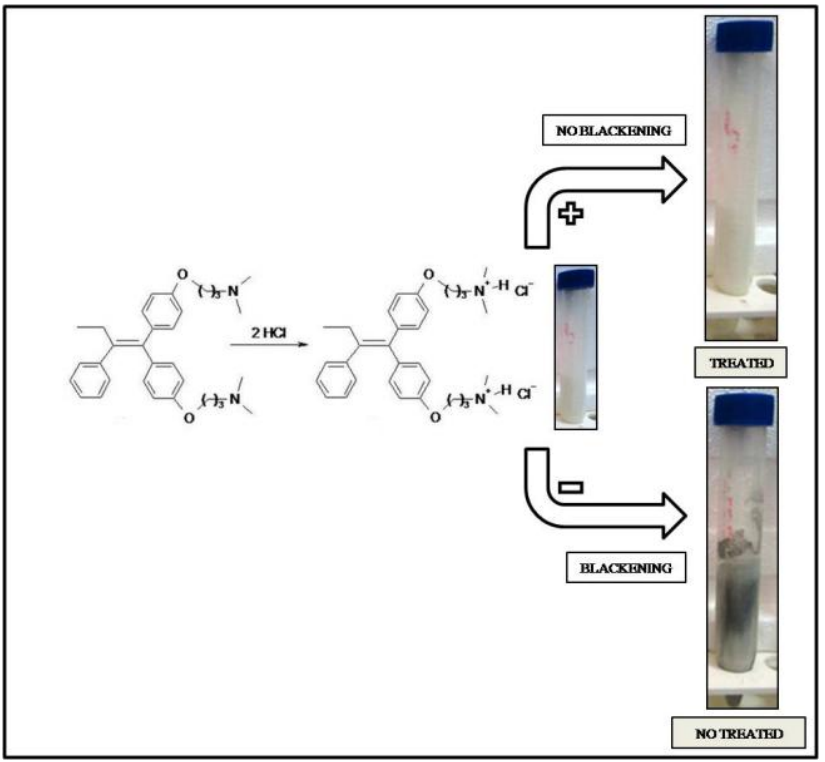

\section{Abstract.}

The biodeterioration and blackening of vinyl glues before their expiration date of use was studied and shown to be of bacterial origin. Two bacterial isolates, responsible for this alteration were isolated and identified as Microbacterium oxydans and Alcaligenes faecalis. This is the first report dealing with Microbacterium oxydans as a vinyl glue deterioration causal agent. Blackening and deterioration were confirmed after glue artificial contamination using the two isolates. The sensitivity of the two contaminant bacteria to various triaryl butenes derivatives, compared to the commercial large used and large spectra biocide (Preventol D6), was assessed for artificially contaminated vinyl glue at different concentrations. Results showed that triaryl butenes have an interesting conservative potential. This was confirmed in vitro by tests demonstrating the activity of the triaryl butenes against glue contaminants. The water-soluble compound 1,1-bis-[4-(3dimethylamoniumpropoxy)phenyl]-2-

ferrocenyl-but-1-ene dichloride shows the most effective performance against glue spoilage and can be proposed as an ecological and economical alternative to traditional biocide formulations. 


\section{Introduction}

The deterioration found in different polymer emulsions, are microorganisms depending effects, like viscosity alteration due to microbial cellulases, gas production associated with fermentative organisms; $\mathrm{pH}$ decrease... By producing hydrogen sulphide, the anaerobic sulfite-reducing bacteria cause blackening and an unpleasant odor. Other color changes could happen by dint of the growth of pigmented organisms such as Rhodotorula and Serratia species [1].

The reduction of the microbiological contamination can be done by a particular attention to water and raw material quality, and respect for good hygiene practices. The use of broad-spectrum bicides can reduce or eliminate the microbial growth [1].

This work aims to isolate the germs responsible for the alteration of the vinyl glue and to test some aryl butene, previously tested in therapeutic [1-5], as conservative.

\section{Materials and Methods}

The commercial biocide used to preserve vinyl glues is Preventol D6 (1). It is a large spectrum activity biocide covering bacteria, fungi and algae. Preventol D6 (CAS No: 55965-84-9), is a mixture of 5chloro-2-methyl-4-isothiazolin-3-one (CMIT), 2-methyl-4-isothiazolin-3-one (MIT) and formaldehyde.

The triaryl butenes (Figure 1), were synthesized by the UMR 8232 of the "Institut Parisien de Chimie Moléculaire". Compounds 1,1-bis[4-(3-dimethylaminopropoxy)phenyl]-2-ferrocenyl-but-1-ene (2) and 1,1-bis[4-(3-dimethylamoniumpropoxy)phenyl]-2-ferrocenyl-but-1-ene dichloride (3) have been previously described [6]. Compound 1,1-bis[4-(3-dimethylaminopropoxy)phenyl]-2-phenyl-but-1-ene dichloride (4) is a newly synthesized compound (scheme 1); it is the $\mathrm{HCl}$ salt of the previously described 1,1-bis[4-(3-dimethylaminopropoxy)phenyl]-2-phenyl-but-1-ene (5) [7].
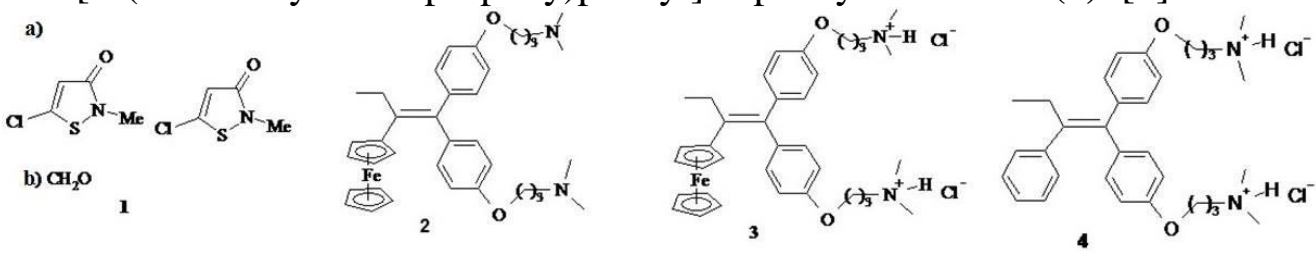

Figure 1: Tested compounds

The diamino compound $5(1.15 \mathrm{~g}, 2.36 \mathrm{mmol})$ was dissolved in $150 \mathrm{ml}$ of diethyl ether and stirred. A $2 \mathrm{M}$ solution of hydrochloric acid in diethyl ether $(2.6 \mathrm{ml}, 5.2 \mathrm{mmol})$ was added drop wise into the solution. A white precipitate was formed. After mixing for $20 \mathrm{~min}$, the mix was filtered under argon. The white solid obtained was washed with $3 \times 5 \mathrm{ml}$ of diethyl ether and dried under vacuum giving 4 in quantitative yield. Crystals contain traces of diethyl ether. ${ }^{1} \mathrm{H}$ NMR (DMSO-d 6 ): $\delta(\mathrm{ppm}) 0.88(\mathrm{t}, J=$ 7.1 Hz, $\left.3 \mathrm{H}, \mathrm{CH}_{3}\right), 2.03-2.30\left(\mathrm{~m}, 4 \mathrm{H}, \mathrm{CH}_{2}\right), 2.37-2.50\left(\mathrm{~m}, 2 \mathrm{H}, \mathrm{CH}_{2}\right), 2.75\left(\mathrm{~d}, J=4.4 \mathrm{~Hz}, 6 \mathrm{H}, \mathrm{NMe}_{2}\right)$, $2.80\left(\mathrm{~d}, J=4.4 \mathrm{~Hz}, 6 \mathrm{H}, \mathrm{NMe}_{2}\right), 3.09-3.32\left(\mathrm{~m}, 4 \mathrm{H}, \mathrm{CH}_{2} \mathrm{~N}\right), 3.94\left(\mathrm{~d}, J=5.1 \mathrm{~Hz}, 2 \mathrm{H}, \mathrm{CH}_{2} \mathrm{O}\right), 4.11(\mathrm{~d}$, $\left.J=5.1 \mathrm{~Hz}, 2 \mathrm{H}, \mathrm{CH}_{2} \mathrm{O}\right), 6.63\left(\mathrm{~d}, J=8.4 \mathrm{~Hz}, 2 \mathrm{H}, \mathrm{C}_{6} \mathrm{H}_{4}\right), 6.76\left(\mathrm{~d}, J=8.4 \mathrm{~Hz}, 2 \mathrm{H}, \mathrm{C}_{6} \mathrm{H}_{4}\right), 6.98(\mathrm{~d}, J=$ $\left.8.4 \mathrm{~Hz}, 2 \mathrm{H}, \mathrm{C}_{6} \mathrm{H}_{4}\right), 7.07-7.29\left(\mathrm{~m}, 7 \mathrm{H}, \mathrm{C}_{6} \mathrm{H}_{4}+\mathrm{C}_{6} \mathrm{H}_{5}\right), 10.84-11.22\left(\mathrm{~m}, 2 \mathrm{H}, \mathrm{NH}^{+}\right) .{ }^{13} \mathrm{C}$ NMR (DMSO$\left.\mathrm{d}_{6}\right): \delta(\mathrm{ppm}) 14.3\left(\mathrm{CH}_{3}\right), 24.7\left(\mathrm{CH}_{2}\right), 24.8\left(\mathrm{CH}_{2}\right), 29.5\left(\mathrm{CH}_{2}\right), 42.8\left(\mathrm{NMe}_{2}\right), 42.9\left(\mathrm{NMe}_{2}\right), 54.8\left(\mathrm{CH}_{2} \mathrm{~N}\right)$, $54.9\left(\mathrm{CH}_{2} \mathrm{~N}\right), 65.6\left(\mathrm{CH}_{2} \mathrm{O}\right), 65.8\left(\mathrm{CH}_{2} \mathrm{O}\right), 114.3\left(2 \mathrm{CH} \mathrm{C}_{6} \mathrm{H}_{4}\right), 115.1\left(2 \mathrm{CH} \mathrm{C}_{6} \mathrm{H}_{4}\right), 127.0\left(\mathrm{CH} \mathrm{C}_{6} \mathrm{H}_{5}\right)$, $128.9\left(2 \mathrm{CH}_{\text {arom }}\right), 130.3$ ( $\left.2 \mathrm{CH}_{\text {arom }}\right), 131.1$ ( $\left.2 \mathrm{CH}_{\text {arom }}\right), 132.4\left(2 \mathrm{CH}_{\text {arom }}\right), 136.4(\mathrm{C}), 136.7(\mathrm{C}), 138.4$ (C), 141.4 (C), 142.9 (C), 157.1 (C), 157.9 (C). IR (KBr, $\left.v \mathrm{~cm}^{-1}\right)$ : 3026, 2961, 2688, 2512, 2474 (CH, $\left.\mathrm{CH}_{2}, \mathrm{CH}_{3}\right)$.

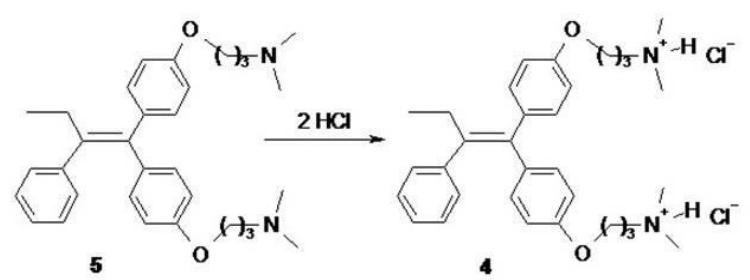

Scheme 1: Synthesis of compound (4)

Vinyl glue is rich in water with a $\mathrm{pH}$ close to neutral, and consists essentially of Poly(vinyl acetate), poly(vinyl alcohol) and calcium carbonate. Altered and freshly made glue samples without biocide were obtained from the manufacture "SIFCOL". 


\section{Results and Discussion}

Viscosity alteration, unpleasant odor of the toxic hydrogen sulfide $\left(\mathrm{H}_{2} \mathrm{~S}\right)$ and blackening are easily detected following vinyl glue deterioration.

Two strains were isolated from an unaltered and altered glue samples and they grow on TSN medium. Their responsibility of glue alteration and blackening was confirmed by artificially glue contaminated with $10^{6} \mathrm{CFU} / \mathrm{ml}$ of the bacteria. Glue blackening occurs after 3 days of incubation.

The bacterial identification, based on morphological, catabolic and molecular methods showed that the first strain is rod, occur singly or in random groups, Gram-positive, motile and do not form endospores. On nutrient agar, colonies appear as a very small yellow circle. It is aerobic catalasepositive, oxidase-negative, gelatin liquefying, urease-negative and $\mathrm{H}_{2} \mathrm{~S}$ producer. The second strain is a rod shaped Gram-negative bacteria, motile, do not form endospores. It shows white colour colonies. It is aerobic catalase-positive, oxidase-positive, gelatin liquefying, urease-negative and $\mathrm{H}_{2} \mathrm{~S}$ producer.

Alignment of the 16S rRNA sequence from the first and the second isolates showed $100 \%$ identity with 16S rRNA sequences of respectively Microbacterium oxydans and Alcaligenes faecalis. So the two strains were assigned as Microbacterium oxydans sp. and Alcaligenes faecalis sp.. Although A. faecalis is a potent and common PVA degrading bacterium, it is the first report of vinyle glue alteration caused by $M$. oxydans, these bacteria are omnipresent on human skin and are the cause of foot odor.

The antibacterial activity of triaryl butenes and compound 1 (Preventol D6) against the two contaminating bacteria was evaluated with MICs and MBCs determination by micro-dilution method (Figure 2). The antimicrobial activity of ferrocenyl or phenyl diamine compounds has been previously demonstrated $[3,5,7,8]$, and proved to be a new application for these compounds.

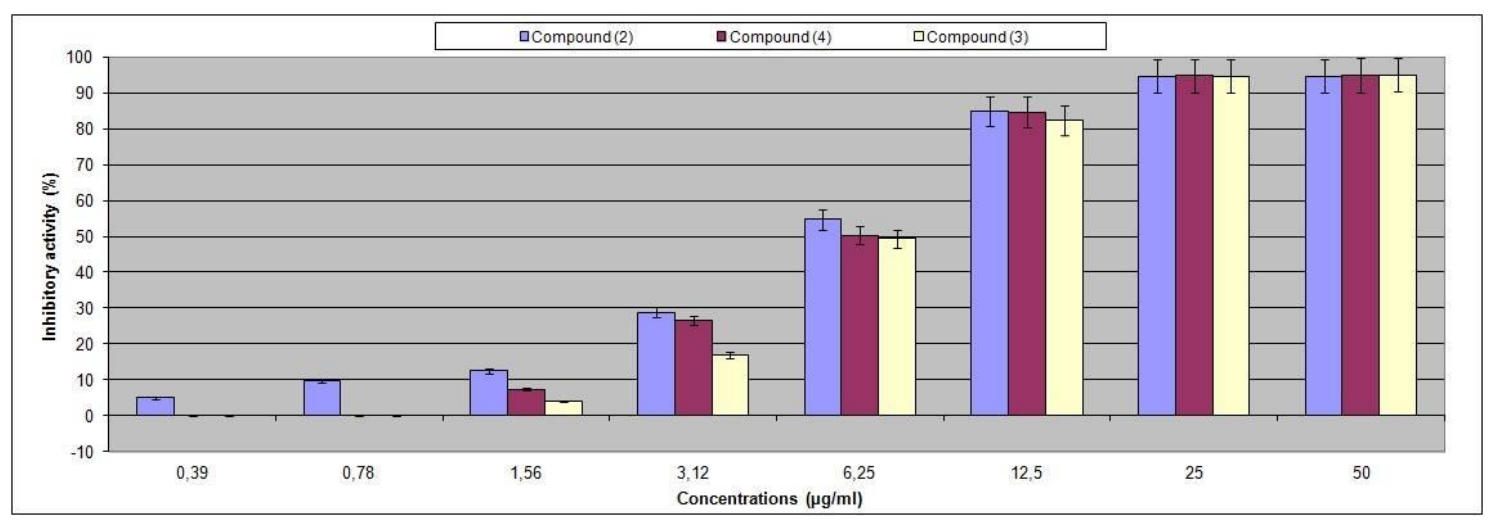

Figure 2: Inhibitor triaryl butene effect on A. faecalis strain, responsible for blackening

These results show the effectiveness of Preventol D6 against the contaminating bacteria with a MIC of $500-1000 \mu \mathrm{g} / \mathrm{ml}$ and a MBC of $2000 \mu \mathrm{g} / \mathrm{ml}$ against a MIC of $125-250 \mu \mathrm{g} / \mathrm{ml}$ and a MBC of $250 \mu \mathrm{g} / \mathrm{ml}$, for both M. oxydans and A. faecalis strain. Despite the use of high biocide dose $(4000 \mu \mathrm{g} / \mathrm{ml})$, which is well superior to its MBC, the commercial biocide (Preventol D6) cannot ensure la preservation of the glue.

These results confirm also high effectiveness of the antimicrobial property of the tested triaryl butenes, which appear to be good candidates as vinyl glue darkening inhibitors, with MIC included and varies between 12,5 and $50 \mu \mathrm{g} / \mathrm{ml}$, and a MBC of $50 \mu \mathrm{g} / \mathrm{ml}$ (1/40 and 1/5 that of Preventol D6 respectively) against the strains $M$. oxydans and A. faecalis (Table1).

Table 1: MIC and MBC of the compounds tested against the blackening causing bacteria

\begin{tabular}{|c|c|c|c|c|}
\hline & Microbacterium oxydans & \multicolumn{2}{|c|}{ Alcaligenes faecalis } \\
\hline Products & $\begin{array}{c}\text { MIC } \\
(\mu \mathrm{g} / \mathbf{m l})\end{array}$ & $\begin{array}{c}\text { MBC } \\
(\mu \mathrm{g} / \mathbf{m l})\end{array}$ & $\begin{array}{c}\text { MIC } \\
(\boldsymbol{\mu g} / \mathbf{m l})\end{array}$ & $\begin{array}{c}\text { MBC } \\
(\mu \mathrm{g} / \mathbf{m l})\end{array}$ \\
\hline Preventol D6 (1) & $(500-1000)$ & 2000 & $(125-250)$ & 250 \\
\hline $\begin{array}{c}\text { 1,1-bis[4-(3-dimethylaminopropoxy)phenyl]-2- } \\
\text { ferrocenyl-but-1-ene (2) }\end{array}$ & $(12,5-25)$ & 50 & $(12,5-25)$ & 50 \\
\hline $\begin{array}{c}\text { 1,1-bis[4-(3-dimethylamoniumpropoxy)phenyl]- } \\
\text { 2-ferrocenyl-but-1-ene dichloride (3) }\end{array}$ & $(25-50)$ & 50 & $(12,5-25)$ & 50 \\
\hline $\begin{array}{c}\text { 1,1-bis[4-(3-dimethylaminopropoxy)phenyl]-2- } \\
\text { phenyl-but-1-ene dichloride (4) }\end{array}$ & $(25-50)$ & 50 & $(12,5-25)$ & 50 \\
\hline
\end{tabular}


Pots of microbiologically controlled manufacture of glue were incubated for 90 days at $30^{\circ} \mathrm{C}$, in sterile jars, in presence or absence of conservatives. After 3 months of incubation, the pots did not show any sign of alteration giving evidence for chemical stability of the glue. It is therefore clear that the alteration is not due to chemical decomposition, and it's of microbial origin. This was confirmed by inoculated glue by the strains $M$. oxydans and A. faecalis and incubated with a $10^{6} \mathrm{CFU} / \mathrm{ml}$ at the same conditions reported previously.

In the same way, the effects of preservatives were monitored for artificially contaminated glue. As shown in figure 3 as an example, the compounds Preventol D6 (1) and 1,1-bis[4-(3dimethylamoniumpropoxy)phenyl]-2-ferrocenyl-but-1-ene dichloride 3, at $200 \mu \mathrm{g} / \mathrm{ml}$ and $50 \mu \mathrm{g} / \mathrm{ml}$ respectively, inhibit the glue darkening artificially contaminated with a $10^{6} \mathrm{CFU} / \mathrm{ml}$ of $\mathrm{A}$. faecalis strain. This result is in agreement with the recovered MBC $(250 \mu \mathrm{g} / \mathrm{ml}$ for Preventol D6 (1) and 50 $\mu \mathrm{g} / \mathrm{ml}$ for 1,1-bis[4-(3-dimethylamoniumpropoxy)phenyl]-2-ferrocenyl-but-1-ene dichloride (3)).

Similarly, compound 1,1-bis[4-(3-dimethylaminopropoxy)phenyl]-2-ferrocenyl-but-1-ene (2), which is as effective as 1,1-bis[4-(3-dimethylamoniumpropoxy)phenyl]-2-ferrocenyl-but-1-ene dichloride (3) in terms of MIC and MBC, did not inhibit blackening of the artificially contaminated glue even at a dose of $100 \mu \mathrm{g} / \mathrm{ml}$ which is the double of its MBC. This can be explained by the fact that compound 1,1bis[4-(3-dimethylaminopropoxy)phenyl]-2-ferrocenyl-but-1-ene (2) is insoluble in water and that the biocide has to be water soluble in order to preserve the microbiological stability of the glue.

\section{Conclusions}

To reveal the microbial cause of the vinyl glue blackening, two contaminating bacteria were isolated and assigned as $M$. oxydans and A. faecalis. The vinyl glue contaminated with the isolated bacteria led to its alteration by blackening in less than one week, confirming that they are the alteration causing agent.

The study of the antimicrobial activity of the commercial biocide Preventol D6 and triaryl butenes 2, 3 and 4, showed that the strains causing the alteration were sensitive to Preventol D6 at the tested doses whereas $\mathbf{2}, \mathbf{3}$ and $\mathbf{4}$ were more effective, compared to the commercial product.

The exploration of glues stability contaminated with the isolated strains proves the importance of the biocide to be water-soluble. In addition to its relatively high MIC and MBC, the commercially used preservative, Preventol D6, has practically less than one year shelf life. Due to this disadvantage, the triaryl butenes studied can be proposed as alternatives since they are more thermostable and extended storage stability.

Finally, this work is an original case study investigating the microbial deterioration and blackening of vinyl glues as well as the approval of a triaryl butene derivative as a potential candidate for a new generation of industrial biocide. 


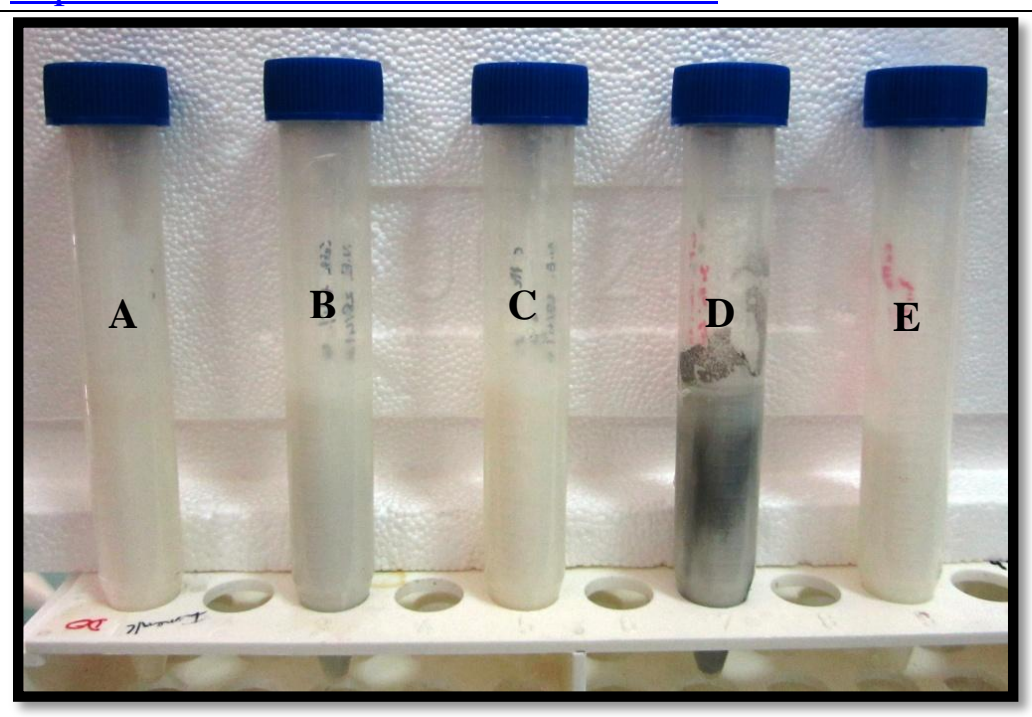

1) A : $800 \mu \mathrm{g} / \mathrm{g}$ - B: $400 \mu \mathrm{g} / \mathrm{g}$ - C : $200 \mu \mathrm{g} / \mathrm{g}$ - D : (+) Control - E : (-) Control

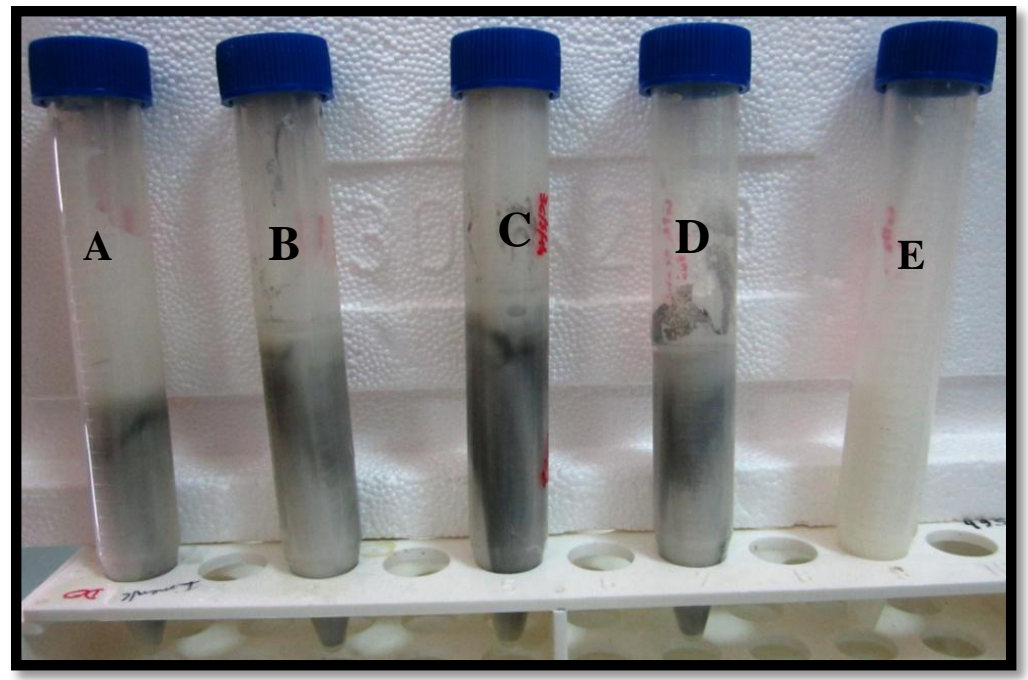

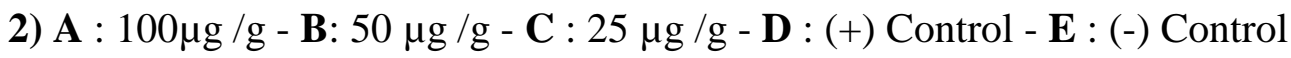

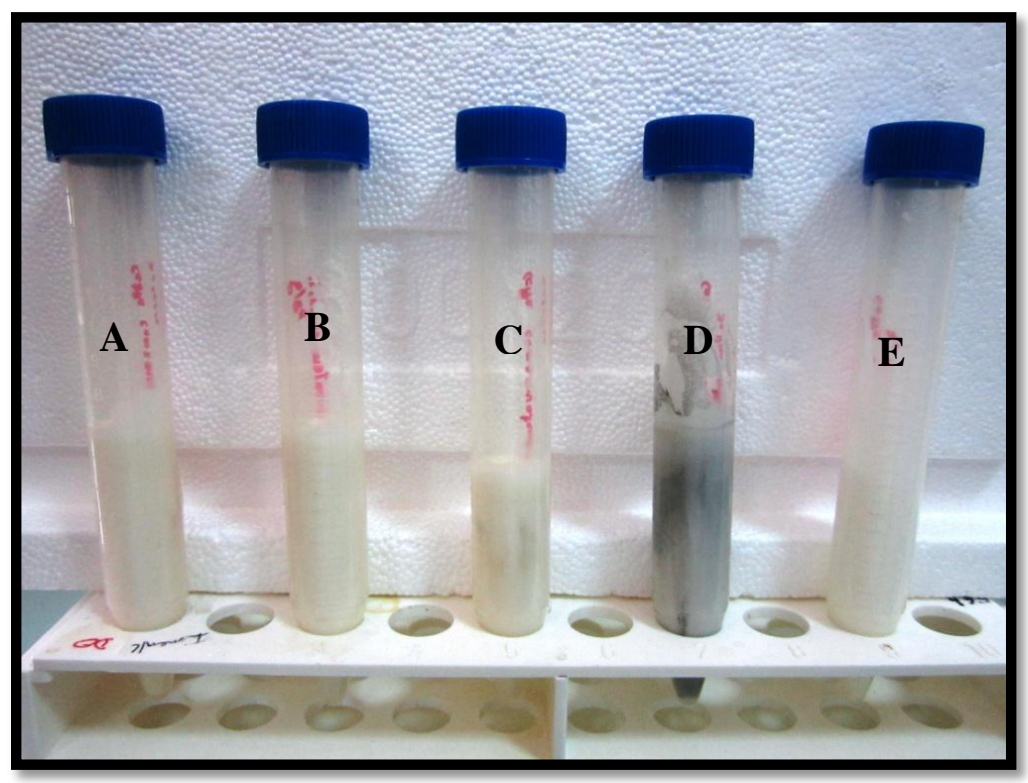

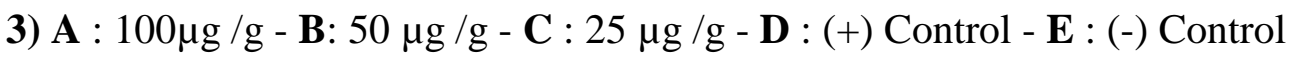

Figure 3: Stability of glue artificially contaminated by A. faecalis strain and added with various concentrations of the products (1), (2) and (3) (after 7 days of storage) 


\section{References}

1. Gillatt, J., 1990. The Biodeterioration of Polymer Emulsion and its Prevention with Biocides. International Biodeterioration 26, 205-216.Gillatt, J., 1991. Methods for the efficacy testing of industrial biocides 1. Evaluation of wet-state preservatives. International Biodeterioration 27, 383394.

2. El Arbi, M., Pigeon, P., Chaari Rkhis, A., Top, S., Rhouma, A., Rebai, A., Jaouen, G., Aifa, S., 2011. Antimicrobial effect of ferrocenyl diaryl butenes against olive plantlet diseases. Journal of Plant Pathology 93 (3), 651.

3. Jellali, K., Pigeon, P., Trigui, F., Top, S., Aifa, S., Jaouen, G., El Arbi, M., 2013. Effect of the amino chain length and the transformation into citric acid salts of aryldiphenyl-butenes and ferrocenyl-diphenylbutenes bearing two dimethylaminoalkyl chains on their antimicrobial activities. SpringerPlus 2,508.

4. Trigui, F., Pigeon, P., Jalleli, K., Top, S., Aifa, S., El Arbi, M., 2013. Selection of a Suitable Disc Bioassay for the Screening of Anti-Tumor Molecules. International journal of Biomedical science 9, 230.

5. El Arbi, M., Théolier, J., Pigeon, P., Jellali, K., Trigui, F., Top, S., Aifa, S., Fliss, I., Jaouen, G., Hammami, R., 2014. Antibacterial properties and mode of action of new triaryl butane citrate compounds. European Journal of Medicinal Chemistry 76, 408.

6. El Arbi, M., Pigeon, P., Top, S., Rhouma, A., Aifa, S., Rebai, A., Vessières, A., Plamont, M.A., Jaouen, G., 2011(b). Evaluation of bactericidal and fungicidal activity of ferrocenyl or phenyl derivatives in the diphenyl butene series. Journal of Organometallic Chemistry 696, 1038.

7. Pigeon, P., Top, S., Vessières, A., Huché, M., Gormen, M., El Arbi, M., Plamont, M.A., McGlinchey, M.J., Jaouen, G., 2011. A new series of ferrocifen derivatives, bearing two aminoalkyl chains, with strong antiproliferative effects on breast cancer cells. New Journal of Chemistry 35, 2212.

8. El Arbi, M., Jalléli, K., Trigui, F., Pigeon, P., Görmen, M., Top, S., Aifa, S., Fliss, S., Jaouen, G., Hammami, R., 2016. Efficacy of a novel ferrocenyl diaryl butene citrate compound as a biocide for preventing healthcare-associated infections. Med. Chem. Commun. 7, 948-954. 